\title{
Nucleolar-persistence phenomenon during spermatogenesis in genus Meccus (Hemiptera, Triatominae)
}

\author{
F.F. Madeira ${ }^{1}$, A.A.C. Lima' ${ }^{1}$, J.A. Rosa ${ }^{2}$, M.T.V. Azeredo-Oliveira ${ }^{1}$ and K.C.C. Alevi ${ }^{1}$ \\ ${ }^{1}$ Laboratório de Biologia Celular, Departamento de Biologia, \\ Instituto de Biociências, Letras e Ciências Exatas, \\ Universidade Estadual Paulista "Júlio de Mesquita Filho", \\ São José do Rio Preto, SP, Brasil \\ 2Laboratório de Parasitologia, Departamento de Ciências Biológicas, \\ Faculdade de Ciências Farmacêuticas, \\ Universidade Estadual Paulista "Júlio de Mesquita Filho", Araraquara, SP, Brasil \\ Corresponding author: K.C.C. Alevi \\ E-mail: kaiochaboli@hotmail.com \\ Genet. Mol. Res. 15 (1): gmr.15017427 \\ Received August 11, 2015 \\ Accepted November 13, 2015 \\ Published March 24, 2016 \\ DOI http://dx.doi.org/10.4238/gmr.15017427
}

ABSTRACT. The Triatominae subfamily consists of 150 species in 18 genera, grouped into six tribes. In cytogenetics, triatomines are important biological models because they have holocentric chromosomes and nucleolar persistence in meiosis. The phenomenon of nucleolar persistence has been described for 23 species of triatomine in three genera: Triatoma, Rhodnius, and Panstrongylus. However, new species and genera should be analyzed to assess whether nucleolar persistence is a peculiarity of Triatominae. Thus, this study aimed to analyze nucleolar behavior during spermatogenesis of Meccus pallidipennis and M. longipennis, focusing on the nucleolar-persistence phenomenon. Through the analysis of spermatogenesis, more specifically of meiotic metaphase, we observed the phenomenon of nucleolar persistence in $M$. pallidipennis and $M$. longipennis, represented by remnants of nucleolar material in metaphase. 
Thus, although nucleologenesis of new species, and, especially, new genera, should be analyzed, this study confirms for the first time the phenomenon of nucleolar persistence in the genus Meccus. Therefore, we emphasize the importance of new studies in this area in order to assess whether this phenomenon is truly a synapomorphy of these hematophagous insects.

Key words: Cytogenetics; Nucleolus; Meiosis

\section{INTRODUCTION}

The triatomines (Hemiptera: Reduviidae) are included in the subfamily Triatominae (Lent and Wygodzinsky, 1979). To date, 150 species in 18 genera have been described (Alevi et al., 2015a). The importance of the triatomines in parasitology is due to these insects being transmitters of the etiologic agent of Chagas disease, Trypanosoma cruzi (Kinetoplastida, Trypanosomatidae) (Tavares and Azeredo-Oliveira, 1996), a flagellate parasite that infects many mammals, including humans (Dias, 2002).

In cytogenetics, triatomines are important biological models because they have holocentric chromosomes, which have diffuse kinetochores. Furthermore, these insects also undergo an unusual form of meiosis in which the segregation of sex chromosomes is post-reductional (Barth, 1956; Ueshima, 1966). In addition, these insects have nucleolar persistence during spermatogenesis (Tartarotti and Azeredo-Oliveira, 1999). Chromosome data are being applied in the taxonomy of these vectors (Alevi et al., 2013a,b,c, 2014a,b, 2015b,c).

Nucleolar persistence is defined by the presence of the nucleolus or nucleolar corpuscles during meiotic metaphase. This phenomenon has been described for 23 species of triatomine within the genera Triatoma (Severi-Aguiar and Azeredo-Oliveira 2005; Severi-Aguiar et al., 2006; Morielle-Souza and Azeredo-Oliveira, 2007; Bardella et al., 2008; Costa et al., 2008; Alevi et al., 2013d; Borgueti et al., 2015; Pereira et al., 2015), Rhodnius (Morielle and Azeredo-Oliveira, 2004; Morielle-Souza and Azeredo-Oliveira, 2007; Alevi et al., 2014c), and Panstrongylus (Tartarotti and Azeredo-Oliveira, 1999). However, new species and genera should be analyzed to assess whether nucleolar persistence is really a peculiarity of the Triatominae subfamily.

The genus Meccus was proposed for Conorhinus phyllosoma. By means of the cladodios, the rostrum, and the insertion of antennae, Meccus was considered synonymous with Triatoma (Pinto, 1927). After conducting laboratory studies, Mazzotti and Osório (1942) proposed that three species of Triatoma should be considered as subspecies of $T$. phyllosoma. On the basis of unequal size in respect to Triatoma species, Carcavallo et al. (2000) proposed revalidation of the genus Meccus. The proposed revalidation of the genus was confirmed by Hypša et al. (2002) based on molecular systematics. Currently, the genus consists of six species, M. phyllosomus, $M$. pallidipennis, M. picturatus, M. longipennis, M. mazzotti, and M. bassolsae (Galvão et al., 2003).

Meccus longipennis is considered the main species of the Meccus complex and is responsible for the transmission of T. cruzi in West Mexico (Lozano-Kasten et al., 2008). This species is founded in both domestic and wild ecotopes (WHO, 2002; Martínez-lbarra et al., 2003) and presents a high capacity to colonize human dwellings (Espinoza-Gómez et al., 2002). Meccus pallidipennis is also considered to be an important vector of Chagas disease, since it is responsible for $74 \%$ of the vectorial transmission to humans in Mexico (Ibarra-Cerdeña et al., 2009). Its 
distribution has been associated with different degrees of invasion in human dwellings (Ramsey et al., 2003; Martínez-lbarra et al., 2011).

Thus, in order to evaluate whether nucleolar persistence is a peculiarity of the Triatominae subfamily, the aims of present study were to analyze nucleolar behavior during spermatogenesis of M. pallidipennis and $M$. longipennis, focusing on the phenomenon of nucleolar persistence.

\section{MATERIAL AND METHODS}

Seminiferous tubules of five adult males of M. pallidipennis and M. longipennis (from the "Triatominae Insectarium" installed in Araraquara city, Sao Paulo, Brazil), after being shredded, squashed, and fixed on a cover slip in liquid nitrogen, were stained by silver ion impregnation (Howell and Black, 1980). The biological material was analyzed with a Jenaval light microscope coupled to a digital camera and an image analyzer Axio Vision LE 4.8 (Carl Zeiss Imaging Solutions $\mathrm{Gmb} \mathrm{H})$. The images were magnified by a factor of $1000 \mathrm{X}$.

\section{RESULTS}

Through the analysis of spermatogenesis, more specifically, of the meiotic metaphase, we observed nucleolar persistence in M. pallidipennis (Figure 1) and M. longipennis, which was represented by remnants of nucleolar material in metaphase (Figure 1, arrows).

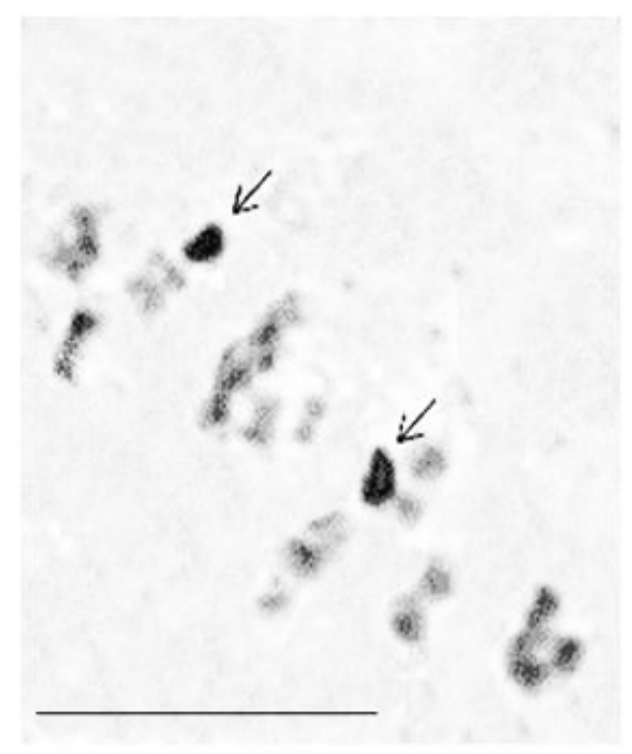

Figure 1. Metaphase I of Meccus pallidipennis. Note the nucleolar persistence (arrows). Bar: $10 \mu \mathrm{m}$.

\section{DISCUSSION}

Spermatogenesis consists of three different phases: spermatocytogenesis, which is a phase of proliferation; meiosis, which is the multiplication phase; and spermiogenesis, which is the 
differentiation phase (Johnson et al., 1997). Both species of Meccus analyzed (M. pallidipennis and M. longipennis) presented the phenomenon of nucleolar persistence during meiosis. It is believed that the persistence of the nucleolus or nucleolar remnants during meiosis in triatomines is an important transcription factor that accumulates mRNA in the cytoplasm or in the formation of a chromatoid body (CB) (Borgueti et al., 2015).

Severi-Aguiar and Azeredo-Oliveira (2005) and Alevi et al. (2014d) showed that the nucleolus, although present during spermiogenesis in insects, is inactivated by epigenetic factors. Recently, Silistino-Souza et al. (2012) and Borgueti et al. (2015) described the cytoplasmic organelle $C B$ in the triatomines. Thus, although further studies should be conducted, we believe that the entire mRNA transcript is stored in the CB during nucleolar persistence in meiosis, and that this organelle is responsible for the differentiation of spermatids to sperm cells (Alevi et al., 2014d; Borgueti et al., 2015).

Thus, although nucleologenesis of new species, and, especially, new genera, should be analyzed, this study confirms for the first time the phenomenon of nucleolar persistence in the genus Meccus. Therefore, we emphasize the importance of new studies in this area in order to assess whether this phenomenon is truly a synapomorphy of these hematophagous insects.

\section{Conflicts of interest}

The authors declare no conflict of interest.

\section{ACKNOWLEDGMENTS}

Research supported by Fundação deAmparo à Pesquisa do Estado de São Paulo (FAPESP; Processes \#2013/19764-0 and \#2015/14762-5) and Conselho Nacional de Desenvolvimento Científico e Tecnológico (CNPq).

\section{REFERENCES}

Alevi KCC, Mendonça PP, Pereira NP, Rosa JA, et al. (2013a). Heteropyknotic filament in spermatids of Triatoma melanocephala and T. vitticeps (Hemiptera, Triatominae). Inv. Rep. Dev 58: 9-12. http://dx.doi.org/10.1080/07924259.2013.793623

Alevi KCC, Mendonça PP, Pereira NP, Guerra AL, et al. (2013b). Distribution of constitutive heterochromatin in two species of triatomines: Triatoma lenti Sherlock and Serafim (1967) and Triatoma sherlocki Papa, Jurberg, Carcavallo, Cerqueira \& Barata (2002). Infect. Genet. Evol. 13: 301-303.http://dx.doi.org/10.1016/..meegid.2012.11.011

Alevi KCC, Mendonça PP, Pereira NP, Rosa JA, et al. (2013c). Spermatogenesis in Triatoma melanocephala (Hemiptera: Triatominae). Genet. Mol. Res. 12: 4944-4947.http://dx.doi.org/10.4238/2013.October.24.5

Alevi KCC, Mendonça PP, Pereira NP, Rosa JA, et al. (2013d). Análise das Regiões Organizadoras Nucleolares e da atividade nucleolar em Triatoma melanocephala e T. lenti, importantes vetores da doença de Chagas. Rev. Cienc. Farm. Básica Apl. 34: 417-421.

Alevi KCC, Rosa JA, Azeredo-Oliveira MT and Azeredo-Oliveira MTV (2014a). Distribution of constitutive heterochromatin in Triatoma melanocephala (Hemiptera, Triatominae). Genet. Mol. Res. 13: 7899-7903.http://dx.doi.org/10.4238/2014. September.29.2

Alevi KCC, Rosa JA and Azeredo-Oliveira MT (2014b). Cytotaxonomy of the Brasiliensis subcomplex and the Triatoma brasiliensis complex (Hemiptera: Reduviidae: Triatominae). Zootaxa 3838: 583-589.http://dx.doi.org/10.11646/ zootaxa.3838.5.7

Alevi KCC, da Costa Castro NF, Lima ACC, Ravazi A, et al. (2014c). Nucleolar persistence during spermatogenesis of the genus Rhodnius (Hemiptera, Triatominae). Cell Biol. Int. 38: 977-980.http://dx.doi.org/10.1002/cbin.10297

Alevi KCC, Mendonça PP, Pereira NP, Rosa JA, et al. (2014d). Is there post-meiotic transcriptional activity during hemipteran spermiogenesis? Inv. Rep. Dev 58: 9-12. http://dx.doi.org/10.1080/07924259.2013.793623 
Alevi KCC, Moreira FFF, Jurberg J and Azeredo-Oliveira MTV (2015a). Description of diploid chromosome set of Triatoma pintodiasi (Hemiptera, Triatominae). Genet. Mol. Res., in press.

Alevi KCC, de Oliveira J, Moreira FFF, Jurberg J, et al. (2015b). Chromosomal characteristics and distribution of constitutive heterochromatin in the Matogrossensis and Rubrovaria subcomplexes. Infect. Genet. Evol. 33: 158-162.http://dx.doi. org/10.1016/j.meegid.2015.04.024

Alevi KCC, Borsatto KC, Moreira FFF, Jurberg J, et al. (2015c). Karyosystematics of Triatoma rubrofasciata (De Geer, 1773) (Hemiptera: Reduviidae: Triatominae). Zootaxa 3994: 433-438.http://dx.doi.org/10.11646/zootaxa.3994.3.7

Bardella VB, Azeredo-Oliveira MTV and Tartarotti E (2008). Cytogenetic analysis in the spermatogenesis of Triatoma melanosoma (Reduviidae; Heteroptera). Genet. Mol. Res. 7: 326-335.http://dx.doi.org/10.4238/vol7-2gmr411

Barth R (1956). Estudos anatômicos e histológicos sôbre a subfamília Triatominae (Hemiptera, Reduviidae). VI. Estudo comparativo sôbre a espermiocitogênese das espécies mais importantes. Mem. Inst. Oswaldo Cruz 54: 599-623.http:// dx.doi.org/10.1590/S0074-02761956000300009

Borgueti AdeO, Alevi KCC, Silistino-Souza R, Rosa JA, et al. (2015). Immunofluorescence and ultrastructural analysis of the chromatoid body during spermatogenesis of Triatoma platensis and T. rubrovaria (Hemiptera, Triatominae). Micron 74: 44-46.http://dx.doi.org/10.1016/j.micron.2015.04.002

Carcavallo RU, Jurberg J, Lent H, Noireau F, et al. (2000). Phylogeny of the Triatominae (Hemiptera: Reduviidae). Proposals for taxonomic arrangements. Entom. Vect. 7: 1-99.

Costa LC, Azeredo-Oliveira MTV and Tartarotti E (2008). Spermatogenesis and nucleolar activity in Triatoma klugi (Triatominae, Heteroptera). Genet. Mol. Biol. 31: 438-444. http://dx.doi.org/10.1590/S1415-47572008000300008

Dias JCP (2002). Controle da doença de Chagas no Brasil: El control de la enfermedad de Chagas en los países del cono sur de América, In: Silveira AC editor., Faculdade de Medicina do Triângulo Mineiro, Uberaba, 145-250.

Espinoza-Gómez F, Maldonado-Rodríguez A, Coll-Cárdenas R, Hernández-Suárez CM, et al. (2002). Presence of triatominae (Hemiptera, Reduviidae) and risk of transmission of Chagas disease in Colima, México. Mem. Inst. Oswaldo Cruz 97: 25-30.http://dx.doi.org/10.1590/S0074-02762002000100002

Galvão C, Carcavallo RU, Rocha DS and Jurberg J (2003). A checklist of the current valid species of subfamily Triatominae Jeannel, 1919 (Hemiptera, Reduviidae) and their geographical distribution, with nomenclatural and taxonomic notes. Zootaxa 202: 1-36.

Howell WM and Black DA (1980). Controlled silver-staining of nucleolus organizer regions with a protective colloidal developer: a 1-step method. Experientia 36: 1014-1015.http://dx.doi.org/10.1007/BF01953855

Hypša V, Tietz DF, Zrzavý J, Rego ROM, et al. (2002). Phylogeny and biogeography of Triatominae (Hemiptera: Reduviidae): molecular evidence of a New World origin of the Asiatic clade. Mol. Phylogenet. Evol. 23: 447-457.http://dx.doi. org/10.1016/S1055-7903(02)00023-4

Ibarra-Cerdeña CN, Sánchez-Cordero V, Townsend Peterson A and Ramsey JM (2009). Ecology of North American Triatominae. Acta Trop. 110: 178-186.http://dx.doi.org/10.1016/j.actatropica.2008.11.012

Johnson L, Blanchard TL, Varner DD and Scrutchfield WL (1997). Factors affecting spermatogenesis in the stallion. Theriogenology 48: 1199-1216.http://dx.doi.org/10.1016/S0093-691X(97)00353-1

Lent $\mathrm{H}$ and Wygodzinsky P (1979). Revision of the Triatominae (Hemiptera: Reduviidae) and their significance as vector of Chagas's disease. Bull. Am. Mus. Nat. Hist. 163: 123-520.

Lozano-Kasten F, Magallón-Gastélum E, Soto-Gutiérrez M, Kasten-Monges M, et al. (2008). [Epidemiologic knowledge and current situation of Chagas disease in the state of Jalisco, Mexico]. Salud Publica Mex. 50: 508-515.http://dx.doi. org/10.1590/S0036-36342008000600012

Martínez-Ibarra JA, Grant-Guillén Y and Martínez-Grant DM (2003). Feeding, defecation, and development times of Meccus longipennis Usinger, 1939 (Hemiptera: Reduviidae: Triatominae) under laboratory conditions. Mem. Inst. Oswaldo Cruz 98: 899-903.http://dx.doi.org/10.1590/S0074-02762003000700007

Martínez-Ibarra JA, Valencia-Navarro I, León-Saucedo S, Ibáñez-Cervantes G, et al. (2011). Distribution and infection by Trypanosoma cruzi of triatomines (Hemiptera: Reduviidae) in the state of Michoacan, Mexico. Mem. Inst. Oswaldo Cruz 106: 445-450.http://dx.doi.org/10.1590/S0074-02762011000400010

Mazzotti L and Osório MT (1942). Cruzamientos experimentales entre varias espécies de triatomas. Rev. Mex. Med. 412: 215-222.

Morielle A and Azeredo-Oliveira MTV (2004). Description of the nucleolar activity and karyotype in germinative cell lines of Rhodnius domesticus (Triatominae, Heteroptera). Caryologia 57: 31-37. http://dx.doi.org/10.1080/00087114.2004.10589369

Morielle-Souza A and Azeredo-Oliveira MTV (2007). Differential characterization of holocentric chromosomes in triatomines (Heteroptera, Triatominae) using different staining techniques and fluorescent in situ hybridization. Genet. Mol. Res. 6: 713-720.

Pereira NP, Alevi KCC, Mendonça PP and Azeredo-Oliveira MTV (2015). Spermatogenesis and nucleolar behavior in Triatoma vandae and Triatoma williami (Hemiptera, Triatominae). Genet. Mol. Res. 14: 12145-12151.http://dx.doi. 
org/10.4238/2015.October.9.2

Pinto C (1927). Classification de genres d'hemiptères de la famille Triatomidae (Reduvidioidea). Bol. Biol. 8: 103-114.

Ramsey JM, Ordóñez R, Tello-López A, Pohls JL, et al. (2003). Actualidades sobre la epidemiología de la enfermedad de Chagas en México. In: Iniciativa para la vigilancia y el control de la enfermedad de Chagas en la República Mexicana (Ramsey JM, López AT and Pohls JL, eds.). Cuernavaca, México, Instituto Nacional de Salud Pública, 85-103.

Severi-Aguiar GDC and Azeredo-Oliveira MT (2005). Cytogenetic study on three species of the genus Triatoma (Heteroptera:Reduviidae) with emphasis on nucleolar organizer regions. Caryologia 58: 293-299. http://dx.doi.org/10.10 80/00087114.2005.10589466

Severi-Aguiar GDC, Lourenço LB, Bicudo HEMC and Azeredo-Oliveira MTV (2006). Meiosis aspects and nucleolar activity in Triatoma vitticeps (Triatominae, Heteroptera). Genetica 126: 141-151.http://dx.doi.org/10.1007/s10709-005-1443-2

Silistino-Souza R, Peruquetti RL, Taboga SR and Vilela de Azeredo-Oliveira MT (2012). Chromatoid body: remnants of nucleolar proteins during spermatogenesis in triatomine (Heteroptera, Triatominae). Micron 43: 954-960.http://dx.doi. org/10.1016/j.micron.2012.03.017

Tartarotti E and Azeredo-Oliveira MTV (1999). Patterns of nucleolar activity during spermatogenesis of two triatomines, Panstrongylus megistus and P. herreri. Caryologia 52: 177-184. http://dx.doi.org/10.1080/00087114.1998.10589171

Tavares MG and Azeredo-Oliveira MTV (1996). Aspectos biológicos e médico sanitários dos triatomíneos. HB Cient 3: 137144.

Ueshima N (1966). Cytotaxonomy of the triatominae (Reduviidae: Hemiptera). Chromosoma 18: 97-122. http://dx.doi. org/10.1007/BF00326447

WHO (World Health Organization) (2002). Control of Chagas'disease, Second Report of a WHO Expert Committee, 107. 